\title{
Child Adoption Implementation without Court Judge Ruling Regarding Law Protection on Inheritance Right in Payakumbuh
}

\author{
Yurike Prastika Putri; Ismansyah; Linda Elmis \\ Faculty of Law, Andalas University, Padang, Indonesia
}

http://dx.doi.org/10.18415/ijmmu.v6i3.925

\begin{abstract}
The objectives of the present research are: 1) to know the Provision of Child Adoption according to Positive Law in Indonesia Viewed from the Perspective of Law Number 35 of 2014 regarding Child Protection; 2) to know the Legal Protection on Child Inheritance Right; 3) to know How the Legal Consequence for the parties in the child adoption without court judge ruling. This is a descriptive research in which the problem approach is judicial empirical and it uses two data sources namely primary data and secondary data. In terms of unknown chilld background, then the child's religion is adjusted to the local community's religion in majority. This child adoption causes legal consequence both for the biological parents that must be responsible for fulfilling all child's needs and for the government. With this child adoption, the biological parents that must be responsible for this can move their obligations to the adoptive parents. By this child adoption, all rights and obligations of the biological parents are moved to the adoptive parents. Besides, the legal consequence for the adoptive parents in this child adoption is the presence of obligation to fulfill all their adopted child's needs as what they give to their biological child.
\end{abstract}

Keywords: Adopted Child Inheritance Right; Adopted Child's Legal Certainty; Legal Protection

\section{Introduction}

Since long ago, child adoption is done by the community with different ways and motivation, as in accordance with the customary law system and living law in the area. The difference in customary law is required a reward as the subsidiary for the adopted child's biological parents in form of sacred object or seen as having magical power. ${ }^{1}$ On the other hand, according to Islamic Law, child adoption is highly recommended as long as it does not dismiss the blood relation between the adopted child and his biological mother; it does not lead to consequence and will with his adoptive parents. However, the last will is applied with maximum $1 / 3$ from the adoptive parents' inheritance as in line with the provision of Article 209 in Islamic Law Compilation. ${ }^{2}$

Child adoption is not an act against the law as long as the child adoption has already been done as the procedure and the provision that have been determined by the prevailing regulations. The Indonesian Positive Law has regulated it regarding Child Adoption as set in Law of Child Protection Number 23 of

\footnotetext{
${ }^{1}$ Wignjodipuro, Soerojo. 1973. Introduction and Principles of Customary Law. Bandung: Alumni, p 31

${ }^{2}$ Iman Jauhari, 2003. Child Rights in Islamic Law, Pustaka Bangsa, Jakarta, p. 163
} 
2002 which has been amanded to Law 35 of 2014 regarding Child Protection and Government Regulation Number 54 of 2007 regarding the Implementation of Child Protection and the Regulation of Social Minister Number 110 of 2009 regarding the requirements of child adoption. ${ }^{3}$

Child adoption which is commonly known as adoption is the law institution which has been known for so long in the culture of Indonesian community. There are some motives why people adopt child; one of them is as the trigger of descent continuation, as the affection factor, and or other reasons.

In the community development, it is seen that the pre-research that is done by the writer with Adillah, a customary figure in Payakumbuh City; he states that the child adoption done by most of customary community of Minangkabau especially in Payakumbuh is generally in form of child adoption from relatives and other people as like becoming the biological child, in the daily treatment, it is like that the child is the adopted child so that the child does not feel underestimated. ${ }^{4}$

Besides, in the legal provision in Indonesia, it does not regulate the child adoption based on the custom yet. However, it only covers inheritance case with the term child born out of wedlock or recognized child.

However, there are several legal regulations regarding child adoption; one of them is Government Regulation Number 54 of 2007 regarding the Implementation of Child Adoption, in which in Article 2, this regulation emphasizes that the child adoption aims the best for the c sake of making the child welfare. ${ }^{5}$

The regulation of child adotion can be found in Government Regulation Number 54 of 2007 regarding the Implementation of Child Adoption, the Regulation of Social Minister Number 110 of 2009 regarding the Requirements of Child Adoption, Circular Letter of Supreme Court Number 2 of 1979 regarding the Procedure of Child Adoption, Circular Letter of Supreme Court Number 6 of 1983 regarding the Improvement of Circular Letter of Supreme Court Number 2 of 1979 regarding the Legitimation Procedure of Child Adoption.

Article 1 point 2 of the Indonesian Government Regulation Number 54 of 2007 regarding the Implementation of Child Adoption determines that:

"Child adoption is a legal action that moves, a child from the parents' power, a legal guardian, or other responsible people on care, education, and growth of child into the adotive parents family environment."

Article 2 of Civil Code regulates regarding the recognition done towards unborn child meaning that the child in the woman's womb, considered as having giving birth, if the child' interest makes it possible. In child adoption, it is not only the movement of responsibility to the adoptive parents, but also the rights and obligations as well as the legal consequences like inheritance if the adoptive parents are dead. $^{6}$

Based on Circular Letter of Supreme Court Number6 of 1983 regarding the Improvement of Circular Letter of Supreme Court Number 2 of 1979 regarding the Legitimation Procedure of Child Adoption, it is mentioned that to adopt a child, it must firstly propose a legitimation request/adoption request to the District Court where the adopted child is in. However, in reality, what happens in the

\footnotetext{
${ }^{3}$ Djaja S.Meliala, 1982, Child Adoption in Indonesia, Tarsito, Bandung, p. 3.

${ }^{4}$ Interview with Mrs. Adillah, done in 10 September 2016

${ }^{5}$ Ali Afandi, 1997, Inheritance Law, Family Law, Proving Law, Rieneka Cipta, Jakarta, p 45

${ }^{6}$ Effendi Parangin, 2005, Inheritance Law, PT. Raja Grafindo Persada, Jakarta., p 20
} 
community is that the adoption process is not through adoption request to the District Court. It is like the spouse namely Yusneli and Rais who adopt a child without proposing a request to the District Court of Payakumbuh.

\section{Research Method}

Based on the objectives that are expected to achive in this research, the research result will be analytical descriptive which is explaining or giving data as detail as possible regarding a condition or other tendencies. It is descriptive because it is expected to obtain whole and systematic explanation regarding "The Implementation of Child Adoption without Court Judge Ruling regarding Legal Protection on Inheritance Right in Payakumbuh".

A judicial empirical approach method is a procedure used to solve research problems by examining secondary data first and presenting a research towards primary data in the field; it means that a judicial empirical approach method is seeing the Implementation of Child Adoption without Court Judge Ruling regarding Legal Protection on Inheritance Right in Payakumbuh by considering whether it has been in accordance with the prevailing regulation. The data collection tool used in this research is document study and interview. After primary data, secondary data is obtained; then, the data are selected, arranged, and analyze qualitatively which is without using statistical formulas. The data are then translated logically and systematically by using deductive and inductive method so that this activity is expected to be able to obtain answers and conclusion which are in line with the research problems and objectives and presented in a descriptive form.

\section{Research Result and Discussion}

1. Regulation of Child Adoption according to Positive Law in Indonesia Viewed from the Perspective of Law Number 35 of 2014 regarding Child Protection.

Article 250 of Civil Code states that every child who is born and grown during the marriage obtains a husband as the father. This article is more focused on the blood descent relation between the parents who raise it during marriage. It needs to be known that the legal child has an absolute part in inheritance and in accordance with the Article 913 of Civil Code as follows, the absolute part or legitime portie is a part of an inheritance that must be given to the heirs in horizontal line according to law, on which part the dead is not allowed to determine something, both as a rewards between the living and as an inheritance. $^{7}$

Ordonantie Staatsblad 1917 Number 129 in Article 12 subsection (2) is if the husband after the marriage is dissolved adopts a son, then the child is considered as having been born from the dissolved marriage because of death. In this article, the law maker has diiferentiated between the words Uit een and uit het. Even though indeed the marriage itself is dissolved by his wife death. Therefore, the adopted child is considered as a legal child from the man but not the child from his ex-wife that is divorced or dead. In this article, it does not also mention door echscheiding onbonthden (divorce breaking) because if so, then it will create a relation between the ex-wife and the child.

Thus, according to Staatsblad 1917 Number 129 that the adopted child will have consequence off from his biological parents and consequence relation with his adoptive parents is there, so that the adopted child also becomes the heir of his adoptive child. However, this Staatsblad provides another

\footnotetext{
${ }^{7}$ Djaja S. Meliala, 1982, Child Adoption based on Local Custom and Legal Regulation in Indonesia, Nuansa Aulia, Jakarta, p 44
} 
restriction; from the inheritance right of the adopted child, it is that the adopted child only becomes the heir of the inherited part. ${ }^{8}$

Afterwards, Circular Letter of Supreme Court of the Republic of Indonesia Number 6 of 1983 regarding the Improvement of Circular Letter of Supreme Court Number 2 of 1979 in which it is mostly about the improvement of request check of child adoption. This is because the government annunciates that this adoption institution is used by some parties to do legal smuggling in order to enable the process of obtaining Indonesian citizenship and also the presence of concern that child adoption changes the citizenship status of Indonesian citizens adopted by the foreign citizens.

Then, the Supreme Court issues Circular Letter of Supreme Court of the Republic of Indonesia Number 4 of 1989 regarding Child Adoption containing regulation that the requirement for the foreign citizens to adopt Indonesian child must domicile and work permanently in Indonesia at least 3 (three) years. This Circular Letter of Supreme Court is the followed up by the Social Minister that issues Decision Number 4 of 1989 regarding the direction of child adoption implementation in order to give guidance for the sake of permit giving, social report making, and guiding as well as controlling child adoption in order to have similarities in behaving and achieving administrative order.

Adopted child ${ }^{9}$ is a legal action in the context of kinship customary law (descent). If a child has been adopted, he would be placed and accepted in a position equalized both biologically and socially which is previously not attached in the child. Customary kinship law sees that descent is the oneness of ancestors, meaning that two people or more have blood relation with the one ancestor, The legal consequence regarding oneness of ancestors varies in every region. There is a similar principle view that descent is an essential and an absolute part for a clan, race, or relative who expects to be not extinct and expects that the generation is there. If a clan, race, or relative who is worried about facing extinction, they commonly adopt a child.

Child adoption in customary law is not a strange institution. The institution is known widely almost all over Indonesia which is done by various ways and motives. For instance in Java, the adopted child is commonly his own nephew or niece. ${ }^{10}$

The legal consequence of child adoption in the customary law is varied. In Java, for instance, the child adoption does not dismiss the kinship relation between the adopted child and his biological parents. Adopted child comes to his adoptive parents' family as the family member, but is not placed as the biological child to continue the descent of his adoptive father. Besides, in Bali, the child adoption is a legal action that releases the child from the kinship relation of his biological parents and takes the child into the adoptive father's family, so that the child is placed to be the biological child to continue his adoptive father's descent.

\section{Law Protection on Child's Inheritance Right \\ a. Inheritance Right in Customary Community}

The customary law of Minangkabau does not recognize child adoption but it is not forbidden. The customary law of Minangkau only recognizes someone or some people to be the community members which is known as manapek (kemenakan batali ameh). Towards it, a plot of land is given as the life capital, but the inherited land is not to be owned forever meaning that if the niece or the nephew leaves,

\footnotetext{
${ }^{8}$ Muderis Zaini, 1999, Adoption A Review of Three Law Systems, Sinar Grafika, Jakarta, p 20

9 Adopted child : an adopted child who does not deserve to receive inheritance right, WJS. Poerwadarmina, 1998,Kamus Umum Bahasa Indonesia, PN. Balai Pustaka, Jakarta.

${ }^{10}$ Soedaryo Soimin, Compilation of Child Adoption Legal Base, Jakarta:Sinar Grafika 2004,p 93
} 
then siriah baliak ka gagangnyo, pinang baliak ka tampuaknyo, meaning that the land and all gifts are returened to the previous.

\section{b. Inheritance Right in Its Practice.}

In the interview done with Mrs Yusnita as the adoptive parent who adopts a child through District Court Ruling of Payakumbuh that Mrs. Yusnita comes to the Notary Office to make a heir in which the assets had during her life will be given to her adopted child in form of Land Certificate, Car, Motorcycle, and Saving; all is done by Mrs. Yusnita because she really loves her adopted child with the condition that it has been approved by the witness namely her siblings ${ }^{11}$.

In the Civil Code Regulation, there is known as erfstelling or the heir appointment, the appointment towards a person or more to obtain all or most of the heir's inheritance (Article 954 of Civil Code). With the appointment, the position of the heir according to the inheritance is similar to the heir's position according to the law. Therefore, if an adopted child based on his parents' inheritance is adopted to be the heir, he obtains all rights and obligations of a heir.

The different regulation which is different from Islamic Law which is the absence of maximum limit in inheritance giving, but there is known as the absolute part that must be received by the heir (legitieme Portie), so the the inheritance giving is not allowed to cause the decrease of absolute part from what the heir should get in real. ${ }^{12}$

The child adoption done by most customary community of Minangkabau is usually in form of child adoption from relatives and other people as if becoming the biological child, with the rights and obligations like the biological child has without dismissing the legal relation between the adopted child and the biological parents.

In a daily treatment towards the adopted child, it is not perceived that the child is an adopted child. The feeling and the treatment towards the adopted child is same as the other people's treatment on the adopted child. The adoptive parents realize and assume on the assets of adoptive parents are owned and used by the adopted child based on Faraid law. Towards sacred inheritance, the child does not have inheritance right because he is not the member of it.

\section{c. Inheritance Right through Court Ruling}

Child adoption principally must be done through prevailing legal process which is through court ruling. The main objective of child adoption must be through legal process specifically to provide legal certainty and welfare for child and adoptive parents, so that it avoids the presence of a problem in the future. Therefore, it must be determined based on the court institution and prevailing legal regulations.

The presence of a court institution absolutely has a good objective; the objective is to obtain legal certainty, to obtain justice and legality in form of legal documents. Absolutely, the documents containing a statement regarding the occurence of child adoption legally based on law; for the writer, when the child is adopted based on law, then a consequence is there in terms of inheriting rights between the child and the adoptive parents. It is essential for the writer to understand and to analyze the existence of child adoption in legal regulations.

\footnotetext{
${ }^{11}$ Interview Result with Mrs. Yusnita, in 1 July 2017 at 13.00 Local Time

${ }^{12}$ Zainuddin ali,2008, The Implementation of Inheritance Law in Indonesia,,Sinar Grafika,Jakarta,p 26
} 

following: ${ }^{13}$

Therefore, the writer will explain the presence of child adoption based on legal regulation in the

1) The Law of the Republic of Indonesia Number 1 of 1974 regarding Marriage stating that:

Article 42 " a legal child is the child born of a legal marriage";

Article 43 subsection (1) "the child born out of wedlock only has civil relation with the mother and his mother's family"

Article 44 subsection (2) "The court gives a ruling regarding whether it is legal or not on the concern parties' request on it.".

Based on the explanation in the article above, the writer assumes that when a person as the party having the interest to adopt a child, then he must ask for a decision for local court where the child lives. It is done in order that the child adoption is legal based on law so that it guarantees the presence of kinship relation between the adoptive parents and the child especially inheritance relation. that:

2) The Law of the Republic of Indonesia Number 4 of 1979 regarding Child Welfare stating

Article 10 subsection (3) "the removal and the return of adopting rights of parents are determined by the judge ruling";

Article 12 subsection (1) "Child adoption according to custom and habit is done by prioritizing the interest of child's welfare".

Subsection (2) "the interest of child's welfare is in the subsection (1) which is set further in Government Regulation";

Subsection (3) "Child adoption for the interest of child's welfare done out of custom and habit is done based on legal regulations "

One of the objectives of the law itself is to provide a legal certainty and to have legal benefits. From the above explanation, it has been so clear that this legal product is made to protect child and to provide welfare for child. One of the welfare forms given to the child and the adopted child is the parents must be responsible, when they are not responsible, the adopting right is removed through judge ruling as well as the parents who are willing to have adopting right or child can be adopted through judge ruling.

3) The Law of the Republic of Indonesia Number 23 of 2006 regarding Population Administration, stating that: Article 47

a) The record of child adoption is done based on the court ruling in the appelant's place.

b) The record of child adoption as meant in the subsection (1) must be reported by the community to the Implementing Institution that issues Birth Certificate Excerpt no later than 30 (thirty) days after accepting the copy of court ruling by the Community.

\footnotetext{
${ }^{13}$ Law Number 1 of 1974 regarding Marriage

${ }^{14}$ Law Number 4 of 1979 regarding Child Welfare
} 
c) Based on the report in subsection (2), the Civil Recording Official makes a side note in the registration of Birth Certificate and Birth Certificate Excerpt.

\section{d. Inheritance Law out of Court}

The legal consequences that can be raised by the presence of child adoption without a right process that is mostly done by the parents who do not want to be busy with the bureaucracy in this country are:

- It can lead to the misunderstanding between the allowed and the disallowed. For instance, the presence of adopted child makes him as the allowed one in which he cannot get marries with the person that actually can be married to and he also can see the part of the body of other people that should be not allowed.

- The disturbance of kinship relation and its rights. It enables the disturbance of rights and obligations of a family that has been determined in Islam. The legal consequence that causes legal relation between the child and the biological parents are dismissed at all and the new legal relation with the adoptive parents, in terms of guard for example the adopted child is a female moslem; if she gets married, it is possible that the guard is only her biological parents or her siblings and the adoptive parents are not justified to be her marriage guard.

- The presence of adopted child to the adoptive parents' family, it can make a conflict between one descent in the family. In terms of inheritance, for instance, the adopted child does not deserve to be their but he has it which close the portion that should be received by other heirs who deserve it. These legal consequences can happen because the parents' candidates do not have knowledge regarding child adoption and unjustified motivation.

The other legal consequence that can happen if the child adoption done without court ruling, according to the writer, is the absence of legal relation between adoptive parents and also the adopted child because there is no a legal proof that this child adoption is done based on the prevailing regulation. The other consequences that may occur is between right and obligation of respective parties, between adoptive parents and the adopted child cannot be accused. It means here that the right and obligation between the child and the parents become absent because there is no legal law document that regulates right and obligation of the adoptive parents and the adopted child, so that it cannot be accused in the court if a case or a condition that meets all parties, in this case the adoptive parents and the adopted child. ${ }^{15}$

\section{Legal Consequence towards Child Adoption without Court Ruling in Payakumbuh.}

a. Legal Protection towards the Right of Adopted Child where His Adoption is not through Court Ruling.

Article 39 subsection 1 Law Number 23 of 2002 regarding child protection strictly states that the purpose of child adoption or the motivation of child adoption can only be done for the best interest of the child and also can be done based on the local custom and the prevailing regulation. This provision highly provides protection guarantee for the child which is indeed dependent on his parents, thus, the child must be given a protection in order that he can feel safe and comfortable let along as the adopted child who just pass the child adoption process. ${ }^{16}$

The government's attempt to protect the right of the adopted child to be noted and the attempt to decrease the possibility of child trafficking, so that the government's hard work will not stop only limited to issue Legal Regulation and its implementation but also in the implementation order in the field. The

\footnotetext{
${ }^{15}$ Kamil,Ahmad and Fauzan, Law of Child Protection and Child Adoption in Indonesia,Jkt,PT Raja Grafindo Persada,p

${ }^{16}$ Suci Wulandari,Child Adoption,http://Forumadopsianak.wordpress.com/2012/04/Pengangkatan Anak, accessed in 17Sseptember 2017
} 
government must have strategic plan as the implementation of national policy regarding the birth record generally which also includes the handling programs of child adoption record. It is also to fix the service system to the community to be freed from the complicated bureaucracy burden but it is to provide prime service from its quality and quantity. ${ }^{17}$

Regarding to this, the child adoption is one of the important events to be recorded in the civil recording registration. What is meant by Important Events according to Article 1 Number 17 the Law of the Republic of Indonesia Number 23 of 2006 regarding population administration is the event experienced by a person including birth, death, dead birth, divorce, child recognition, child adoption, name change, and citizenship status change. Besides, Article 1 subsection 7 gives an explanation that what is meant by Implementing Institution is the municipal/regency unit who is responsible and is authorized in terms of Population Administration. The definition of Civil Registration according to Article 1 Number 15 is: the record of important events experienced by a person in the civil recording registration by work unit that manages the population registration and civil record.

The child adoption record must be proven by the copy of approval from district court which is court ruling (for non-Moslem) and Religious Court Ruling (for Moslem). It is the base to make a side note in the birth certificate excerpt of the adopted child. Therefore, the adopted child does not have two birth certificate excerpts, but only has one added with side note which is the note regarding the status change on the occurrence of important events in form of note put in the side of the certificate or in the part of certificate if possible (in the page/in the cover or in the back of the certificate) by the Civil Recording Official. $^{18}$

The government is also responsible for the protection on the right of adopted child through child adoption record. The adoptive parents are expected to record the child adoption that has obtained court ruling which is then in the civil record dimension in form of the making of side note in the Birth Certificate Excerpt. The side note in the birth certificate excerpt is the legal proof of the adopted child civil status. The government is expected to implement the prevailing of Law Number 23 of 2006 regarding Population Administration and Government Regulation of the Republic of Indonesia Number 54 of 2007 regarding Child Adoption through Regional Regulation Design.

The interview result with Mrs. Mulyani, Bachelor of Law, as the Junior Registrar, the suit that has been done on Thursday in August 24 in Payakumbuh Religious Court showing that the factor of child adoption consists of two namely internal factor and external factor in which in the internal factor, the adoptive parents candidate does not have a child yet, so that the parents adopt a child, in other words, it is as a trigger to have a child to them; besides, from the external factor, it is because the presence of unattended child so that it triggers feeling of pity on the child because the child does not have a family anymore $^{19}$. Therefore, the child adoption frequently happens in Indonesia, as in line with the regulation of Civil Code of Child Adoption is determiend in the District Court, but after the writer conducts a research in Payakumbuh District Court, there is someone who adopted a child but then he wanted to make it cancelled, and many request proposed to the Religious Court because basically they assume that the adoptive parents candidate and the adopted child are Moslem, so that it is adjusted to their belief that the child adoption is done in the Religious Court.

The process of child adoption without the court ruling is by the making of agreement between the biological parents and the adoptive parents candidate to adopt and educate the adopted child candidate

\footnotetext{
${ }^{17}$ Ahmad Kamil, Law of Child Protection and Child Adoption in Indonesia,,Jakarta Rajawali Pers,2008,p 69

${ }^{18}$ Ibid p 64

${ }^{19}$ Interview result with Mrs. Mulyani, Bachelor of Law, as the Suit Junior Registrar in Payakumbuh Religious Court in 24 August 2017
} 
until adult and can live independently so that the child can fulfill his needs and help his family's economy.

\section{b. The Causing Factor of Child Adoption without Court Ruling in Payakumbuh}

Basically, the child adoption factor in Payakumbuh is same as the child adoption factor in Indonesia. However, in Payakumbuh, the child adoption can be done without court ruling. It basically can lead to harm both for the adoptive parents candidate and the adopted child himself because the absence of legal certainty on the child adoption and eventually the biological parents or the child' family can accuse regarding the inheritance right of the child.

As the interview that has been done by the writer on the adoptive parents namely Yusneli and Rais, whose their adopted child is Muhammad Nanda Kurnia which is done in 2000. Nanda who previously lives in Riau with his biological parents with bad economy and his father has been dead. Firstly, the child is introduced to Yusneli's sibling who lives in Riau and brings him to Payakumbuh to be adopted by Yusneli and Rais with the reason to be a trigger because Yusneli and Rais who have got married for 15 years but still not having a child. Then, they make an agreement that the child will be taken care by Yusneli and Rais and Nanda's biological parent is not allowed to ask the child back. Now, Nanda has grown but he has mental subnormality and must have special attention from Yusneli and Rais, because Yusneli and Rais are old and afraid of passing away faster than Nanda, therefore, they grant their assents in form of a house with Ownership Right Certificate to Nanda, Yusneli and Rais come to the Notary Office to grant the house certificate but what becomes the problem at that time is one of Yusneli's siblings does not want to sign the Grant Certificate because according to him, this is Yusneli's sibling that will receive the grant, thus, an agreement is made between Yusneli and her sibling that the ownership right certificate will be made on behalf of Nanda but it will never be sold and will be occupied by Yusneli's sibling and Nanda must be taken care with full of affection as like their biological child. Thus, they want to grant their assents to their one and only adopted child.

Besides Yusneli and Rais, there is also another spouse who adopt a child without Court Ruling which is done by Sri and Ajo. In the beginning, Sri and Ajo who have got married more than 20 years but not having a child yet because they feel lonely, then they ask for information to the neighbour who has a child or other people's child that can be adopted and grown by Sri and Ajo. Finally, one of the neighbours introduces Sri to a young woman namely Murniati coming from Piladang who is in pregnancy. The reason why Murniati is willing to give her child is because the child's biological father is not willing to be responsible and just leave. Because of feeling shy, then she is ready to give the child after birth to Sri and Ajo with the condition that since the pregancy and the giving birth, Murniati lives in Sri and Ajo's house. After giving birth, Murniati will go. Finally, Murniati gives birth a girl baby who is named Yuli who was born in Juli 2000. There is no written agreement between Sri and Murniati. It is only an oral agreement. Two years later, Sri and Ajo gave birth their first child who was born in 2003 namely Robi and their second child namely Sinta in 2014. Sri and Ajo highly love their children without differentiating one of another. It is same as the first spouse just now, the writer also asked about inheritance that will be shared to their children after they are dead. Sri and Ajo answered that they only have a house in which the house is not for being their children's, but it will be shared house. The house will be occupied if their children go home. Sri educates, takes care with affection of all their children without seeing the status of adopted child and biological child. All child is also sent to school as expected by their child respectively. Sri send their children in order to be smart, independent, and religious children. It is what is expressed by Sri.

The third spouse that the writer interviews is Jasima and Anwar who is also the grandparents of the adopted child namely Rahmat and Ali. The reason why Jasima adopts Rahmat who was born in 2004 and Ali who was born in 2006 because their biological parents were dead and their biological father who is also the biological child from Jasima and Anwar who have got married and went with his new wife 
without any responsibilities towards Rahmat and Ali, Jasima, with her hard work, grows Rahmat and Ali because Jasima is already old, when interview with Mrs. Jasima, the writer asked why she did not adopt a child through court ruling, she said that she did not have money and did not know the procedure to manage the requirements regarding the child adoption.

\section{c. The Child Adoption Process without Court Ruling in Payakumbuh}

The child adoption process without court ruling in Payakumbuh basically is only done simple and based on kinship. It is different from the child adoption who has court ruling. The child adoption with Court Ruling is done through court process like registering a request of child adoption in the court, conducting a trial, and determining child adoption and getting court ruling which is the base of child adoption done, whil if the child adoption does not use court ruling, usually there is an agreement letter between the biological parents and the adoptive parents. After that, the child adopted right has become the responsibility of the adoptive parents.

According to the information stated by Mrs. Mulyani as the Junior Registrar of Suit in Payakumbuh Religious Court, the procedure of child adoption request with court ruling is as follows: ${ }^{20}$

1) The child adoption request by Moslem Indonesian Citizen addressed to Religious Court or Shariah Court in the legal area where the child domiciles. The request is voluntary.

2) The investigation request of child adoption must refer to Circular Letter of the Supreme Court of the Republic of Indonesia Number 2 of 1979, Number 6 of 1983, and Number 3 of 2005.

3) The request above can be made if it is proven having fulfilled the conditions set in Article 39 of Law Number 35 of 2014 regarding Child Protection, Article 5 subsection (2) Law Number 12 of 2006 regarding Indonesian Citizenship, Circular Letter of the Supreme Court of the Republic of Indonesia Number 2 of 1979, Number 6 of 1983, and Number 3 of 2005.

4) The command of child adoption determination aforementioned stating: "legally stating adopting a child done by the appelant named.... son of/daughter of....., address ......., towards a child named ......... son of/daughter of......, aged....".

5) The copy of the child adoption determination is sent to Social Ministry, Ministry of Justice cq. General Directorate of Immigration, Ministry of Foreign Affairs, Ministry of Health, Attorney General of Indonesia, Indonesian National Police, and the Registrar of the Republic of Indonesia Supreme Court.

The child adoption case in District Court before 2002 shows that some adoptive parents do child adoption in the District Court, but after 2002, the adoptive paents prefer doing it through Religious Court with the reason that the adopted child and the adoptive parents candiate are Moslems, so that the child adoption can be done in the Religious Court.

Besides, the process of child adoption done without Court Ruling is simpler and does not waste time too long which is only in form of writter agreement with revenue stamp signed by the biological parents and the adoptive parents and some witnesses who know and agree.

This thesis writing uses 4 (four) theories namely theory of legal certainty, theory of justice, theory of law protection, and theory of social welfare, In this child adoption without court ruling, its legal certainty can be seen from the agreement between the biological parents and the adoptive parents only. It is because of the absence of court ruling in the child adoption process. One of the adoptive parents that has been interviewed indeed proves that the adoptive parents have been responsible for caring and educating the adopted child as like they care and educate their biological child.

\footnotetext{
${ }^{20}$ Interview with Mrs. Mulyani as the Suit Junior Registrar in 19 September 2017
} 
Theory of justice in this case can be seen from the presence of affection and same treatment of what the adoptive parents give to their biological child. It can also be seen from the spouses who have been interviewed that mostly have treated their adopted child like what they do to their biological child.

In the theory of law protection, it can be seen from the presence of an agreement on a stamp which is made between the biological parents and the adoptive parents candidate. Therefore, in the future, there is no more suit towards any kinds of legal consequence as moving the adopting right on the child. In addition, the adopted parents have done their obligations as good parents.

Theory of social welfare in this case can be seen from the presence of inheritance given by adoptive parents to their adopted child. Regarding to the assets they have, it has been given to their adopted child without hampering the right of their biological child. To ensure the welfare of their adopted child, the adoptive parents have seen them to school like their biological child. Even one of them is graduated and married.

By the presence of adoption done by these spouses, automatically it has helped the government in making the community welfare. These unattended children become less because they are taken from their biological parents who have recognized their inability to care and treat as well as educate their biological children. ${ }^{21}$

\section{Conclusion}

1.The child adoption regulation is according to the positive law in Indonesia. HOCI (Huwelijke Ordonnantie Chrissten Indonesiers); Staatsblad 1917 Article 5 until 15 regulates about adoption for Chinese descent citizens and Foreign Eastern that is the completion of existing Civil; Circular Letter of the Supreme Court of the Republic of Indonesia Number 2 of 1979 regarding Child Adoption; Circular Letter of the Supreme Court of the Republic of Indonesia Number 6 of 1983 regarding the Improvement of Circular Letter of the Supreme Court of the Republic of Indonesia Number 2 of 1979 regarding Child Adoption.

Circular Letter of the Supreme Court of the Republic of Indonesia Number 3 of 2005 regarding Child Adoption; Government Regulation of the Republic of Indonesia Number 54 of 2007 regarding the Implementation of Child Adoption; The Decision of Social Minister Number 41/HUK/KPE/VII/1984 regarding the Implementation Direction of Child Adoption Permit.

Law Number 35 of 2014 regarding Child Protection; Law Number 3 of 2006 regarding the Amandment of Law Number 7 of 1989 regarding Religious Court; Law Number 1 of 1974 regarding Marriage and all regulation that regulates about marriage, both in Civil Code, Staatsblad of 1933 Number 75, and the ordinance of mixed marriage in Staatsblad of 1898 number 158; Some Jurisprudence of Supreme Court and Court Decision that has permanent legal power.

2. The causing factor of the parents adopt children not through court ruling is because of the presence of difficult procedure and expensive cost to conduct a trial in the process of child adoption. Also, it can be caued by the biological parents from the adopted child are not there anymore because the presence of kinship relation between the adoptive parents and the biological parents.

The process is done simpler. It is only the agreement between the biological parents and the adoptive parents by making an agreement which is usually in form of written agreement and seen as well

\footnotetext{
${ }^{21}$ Satrio J,Family Law regarding the Position of Child in Law, Bandung,Citra Aditya Bakti,2002,p 49
} 
as signed by some witnesses. The attempts are done by making an agreement between the adoptive parents that they will grow their adopted child well. The legal consequence towards the child adoption without court ruling.

The legal consequence during the agreement of child adoption does not contain any suit, therefore child adoption is legal to be done. Moreover, all rights and obligations of the biological parents are moved to the adoptive parents.

\section{References}

\section{Books}

Adopted Child: an adopted child who does not deserve to receive inheritance right, WJS. Poerwadarmina. (1998). Kamus Umum Bahasa Indonesia, PN. Balai Pustaka, Jakarta.

Ahmad Kamil, Law of Child Protection and Child Adoption in Indonesia,,Jakarta Rajawali Pers.(2008),p 69.

Ali Afandi .(1997). Inheritance Law, Family Law, Proving Law, Rieneka Cipta, Jakarta, p 45.

Djaja S. Meliala .(1982). Child Adoption based on Local Custom and Legal Regulation in Indonesia, Nuansa Aulia, Jakarta, p 44.

Djaja S.Meliala .(1982). Child Adoption in Indonesia, Tarsito, Bandung, p. 3.

Effendi Parangin .(2005). Inheritance Law, PT. Raja Grafindo Persada, Jakarta, p 20.

Iman Jauhari .(2003). Child Rights in Islamic Law, Pustaka Bangsa, Jakarta, p. 163.

Kamil,Ahmad and Fauzan, Law of Child Protection and Child Adoption in Indonesia,Jkt,PT Raja Grafindo Persada,p 21.

Muderis Zaini .(1999). Adoption A Review of Three Law Systems, Sinar Grafika, Jakarta, p 20.

Satrio J,Family Law regarding the Position of Child in Law, Bandung,Citra Aditya Bakti .(2002).p 49.

Soedaryo Soimin, Compilation of Child Adoption Legal Base, Jakarta:Sinar Grafika.(2004).p 93.

Wignjodipuro, Soerojo .(1973). Introduction and Principles of Customary Law. Bandung: Alumni, p 31.

Zainuddin ali .(2008).The Implementation of Inheritance Law in Indonesia,,Sinar Grafika,Jakarta,p 26.

\section{Legislation}

Law Number 1 of 1974 regarding Marriage

Law Number 4 of 1979 regarding Child Welfare

Interview

Interview result with Mrs. Mulyani, Bachelor of Law, as the Suit Junior Registrar in Payakumbuh Religious Court in 24 August 2017. 
Interview with Mrs. Mulyani as the Suit Junior Registrar in 19 September 2017.

Interview with Mrs. Adillah, done in 10 September 2016.

Interview Result with Mrs. Yusnita, in 1 July 2017 at 13.00 Local Time.

\section{Copyrights}

Copyright for this article is retained by the author(s), with first publication rights granted to the journal. This is an open-access article distributed under the terms and conditions of the Creative Commons Attribution license (http://creativecommons.org/licenses/by/4.0/). 